\title{
Porous Ti-Si Alloys for Implants
}

Anna Knaislová, Matyáš Peterka, Pavel Novák, Dalibor Vojtěch

Department of Metals and Corrosion Engineering, Institute of Chemical Technology, Prague

Porous alloys are very perspective materials for medical implants, particularly for surgical and dental applications. The reason - besides their biocompatibility - is their density. This is why the implants and bone replacements are lighter and more similar to a human bone in its structure and mechanical properties. Another advantage is good osseointegration, i.e. tissue growing through pores in the material, this makes the body accept the implant better and there is also no risk of rejection. New Ti-Si biomaterials_were prepared by powder metallurgy using reactive sintering, during which the desired porous structure of the material is formed. In this experiment the observed subject was the microstructure of Ti-Si alloys, properties determined were porosity and yield strength in compression.

Keywords: titanium, silicon, porous, biomaterial

\section{Acknowledgement}

This research was financially supported by Technology Agency of the Czech Republic, project No. TE01020390.

\section{References}

[1] NOVÁK P., SITA L., KNAISLOVÁ A., VOJTĚCH D., Powder metallurgy preparation of porous titanium for medica implants, Metal 2012.

[2] OH I.-H., NOMURA N., MASAHASHI N., HANADA S., Mechanical properties of porous titanium compacts prepared by powder sintering, Scripta Materialia, 49 (2003) 1197-1202

[3] VOJTĚCH D., KUBÁSEK J., VODĚROVÁ M., Structural, mechanical and in vitro corrosion characterization of as-cast magnesium based alloys for temporary biodegradable medical implants, Manufacturing technology, $12 / 2012$, pages $285-292$

[4] GEETHA, M. ET AL., Ti based biomaterials, the ultimate choice for orthopaedic implants - A review, Progress in Materials Science, 54 (2009), 397 - 425.

[5] BARBAS A., BONNET A.S., LIPINSKI P., PESCI R., DUBOIS G, Application of reaction sintering to the manufacturing of a spacecraft combustion chamber of SiC ceramics, Journal of Materials Processing Technology, 192 (2002) 408-411.

[6] NOVÁKOVÁ L., HOMOLA P., KAFKA V., Microstructure Analysis of Titanium Alloys after Deformation by means of Asymmetric Incremental Sheet Forming, Manufacturing technology, 12/2012, pages 201-206

[7] NOVÁK P., MICHALCOVÁ A., MAREK I., VODĚROVÁ M., VOJTĚCH D., Possibilities of the observation of chemical reactions during the preparation of intermetallics by reactive sintering, Manufacturing technology, 12/2012, pages 197-201

[8] RILEY, D.P., Synthesis and characterization of SHS bonded Ti5Si3 on Ti substrates, Intermetallics, 14 (2006), $770-775$.

[9] GEPREEL, M. A.-H., NIINOMI, M., Biocompatibility of Ti-alloys for long-term implantation, Journal of the Mechanical Behavior of Biomedical Materials, 20 (2013), 407 - 415.

[10] ZHANG, L., WU, J., Tis $\mathrm{Si}_{3}$ and $\mathrm{Ti}_{5} \mathrm{Si}_{3}$-based alloys: alloying behavior, microstructure and mechanical property evaluation, Acta Materialia, 46 (1998), 3535 - 3546.

[11] MEYERS, M.A., CHAWLA, K.K. (2009). Mechanical behavior of materials, CAMBRIDGE UNIVERSITY PRESS.

[12] CASTELLANI, C., LINDTNER, R.A., HAUSBRANDT, P., et al. (2011). Bone-implant interface strength and osseointegration: Biodegradable magnesium alloy versus standard titanium control. Acta Biomaterialia, 7, 1, pp. $432-440$. 